Transactions of the Karelian Research Centre of the Russian Academy of Sciences

No. 8. 2019. P. $97-107$

DOI: $10.17076 / \mathrm{bg} 954$
Труды Карельского научного центра РАН

№ 8. 2019. С. 97-107

УДК 591.69-755.251(28:571.1/.5)

\title{
THE PARASITE FAUNA OF COREGONIDS FROM LOWER OB TRIBUTARIES AND THE KHATANGA RIVER
}

\author{
A. L. Gavrilov', Yu. K. Chugunova², E. P. leshko ${ }^{3}$, \\ O. A. Gos'kova', V. D. Bogdanov' \\ ${ }^{1}$ Institute of Plant and Animal Ecology, Ural Branch, Russian Academy of Sciences, \\ Ekaterinburg, Russia \\ ${ }^{2}$ Russian Federal Research Institute of Fisheries and Oceanography, Krasnoyarsk Branch, Russia \\ ${ }^{3}$ Institute of Biology, Karelian Research Centre, Russian Academy of Sciences, Petrozavodsk, Russia
}

\begin{abstract}
A comparative analysis was carried out investigating the parasite faunas of coregonids (humpback whitefish, peled, least cisco, and tugun) from the Lower Ob Ural tributaries (Rivers Synya, Voykar, Severnaya Sos'va, Sob, Shchuch'ya) and from the Khatanga River. Surveys revealed 48 parasite species, most with a complex life cycle (29 helminth species and 3 myxosporidian species whose development involves benthic organisms). Semianadromous whitefish spawning in Lower Ob tributaries were shown to have a poorer species composition of parasites (13-16 species) compared to land-locked whitefish from the Khatanga ( 23 species). The parasite fauna of semi-anadromous peled from the Lower $\mathrm{Ob}$ had the most diverse species composition among the rest of coregonids, with relatively high similarity between the rivers Voykar and Synya, while that of the S. Sos'va River stood apart. Resident ecotypes of peled from the rivers Shchuch'ya and Khatanga were similar in the species composition of their parasites in spite of the substantially different geographical locations of the catchments. Least cisco within the Lower Ob basin (Rivers Voykar and Sob) featured a high similarity of the parasite species composition, which was, however, very different from that in least cisco from the Khatanga. Some freshwater parasites (infusorians, monogeneans, trematodes and leeches) apparently get lost in the brackish waters of Khatangsky Bay, while the crustacean Coregonicola orientalis is introduced into the river during the spawning run. The parasite fauna of tugun was the richest in the Khatanga (17 species), relatively poor in the Sob (5) and Shchuch'ya (6 species), and generally reflected the features of the fish ecology in each specific river.
\end{abstract}

Ke y w o rd s: peled; least cisco; tugun; humpback whitefish; parasites; Lower Ob tributaries; Khatanga River.

\section{А. Л. Гаврилов, Ю. К. Чугунова, Е. П. Иешко, О. А. Госькова, В. Д. Бог- ДаНОВ. ПАРАЗИТОФАУНА СИГОВЫХ РЫБ В ПРИТОКАХ НИЖНЕЙ ОБИ И РЕКЕ ХАТАНГЕ}

Проведен сравнительный анализ паразитофауны сиговых рыб из уральских нерестовых притоков Нижней Оби (рек Сыня, Войкар, Северная Сосьва, Собь, Щучья) и р. Хатанги (полуостров Таймыр). Видовой состав паразитов включает 48 видов, среди которых доминируют гельминты со сложным циклом развития (29 видов, включая 3 вида миксоспоридий, развитие которых проходит с участием бентосных организмов). Полупроходной сиг-пыжьян, нерестящийся в притоках Нижней Оби, 
отличается бедным видовым составом фауны паразитов (13-16 видов) по сравнению с озерно-речной формой сига-пыжьяна из Хатанги (23 вида). Паразитофауна полупроходной пеляди Нижней Оби наиболее разнообразна по сравнению с другими видами сиговых рыб, характеризуется относительным сходством у рыб из рек Войкар и Сыня и выраженной обособленностью в р. Северной Сосьве. Озерноречные формы пеляди из рек Щучья и Хатанга близки по видовому составу паразитов, несмотря на значительные отличия в географическом положении водных бассейнов. Сибирская ряпушка в бассейне Нижней Оби (реки Войкар и Собь) имеет сходный состав паразитов, резко отличающийся от такового у сибирской ряпушки р. Хатанги. Солоноватые воды Хатангского залива, очевидно, приводят к утрате ряда пресноводных паразитов (инфузорий, моногеней, трематод и пиявок), a рачок Coregonicola orientalis заносится в реку во время нерестовой миграции. Паразитофауна тугуна наиболее богата в р. Хатанге (17 видов), обедненная - в реках Собь (5) и Щучья (6 видов) и в целом отражает особенности экологии рыб в конкретной реке.

Ключевые слова: сиговые рыбы; паразитофауна; притоки Нижней Оби; р. Хатанга.

\section{Introduction}

Coregonids are a group with exceptionally high plasticity, whose members actively colonize Arctic waters and form various ecotypes (riverine semi-anadromous, lacustrine-riverine, lacustrine). The food supply at northern latitudes being rather poor and variable, coregonids feed on different food items depending on the development stage and season. Being broadly euryphagous is an important adaptation of coregonid fish living at high latitudes, and the predominant diets of benthos and plankton are complemented with predation or a substantial share of mixed foods [Reshetnikov, 1980]. The species composition of parasites, especially helminths, reflects the dietary and habitat preferences of different coregonid species.

The parasite fauna of Siberian whitefishes began to be studied only in the second half of the previous century. Studies are few and largely fragmentary [Bauer, 1941; Petrushevsky et al., 1948; Lukyanchikov, Cherepanov, 1962; Titova, 1965]. Systematic studies have been conducted in recent decades [Gavrilov et al., 2013; Chugunova, Budin, 2018]. In this paper we aim to comparatively analyze the species diversity of parasites in coregonid fish from Lower Ob Arctic tributaries and from the Khatanga River, to look at the patterns of parasite species richness formation in resident and anadromous ecotypes.

\section{Study areas}

The rivers surveyed in the Ob lower course are left-hand Ural tributaries that are typical mountain streams in their upper course while in their lower course they form intermittent vernal water bodies (vernacular sor) that dry out for the autumn and winter. These rivers are the Severnaya Sos'va the largest tributary, $866 \mathrm{~km}$ long and with ca. $89,700 \mathrm{~km}^{2}$ catchment area; the Shchuch'ya River - the second largest Lower Ob tributary, originating from Lake Bolshoye Shchuchye (river length is $565 \mathrm{~km}$, catchment area is $12,300 \mathrm{~km}^{2}$ ); the rivers Synya and Voykar - 322 and $110 \mathrm{~km}$ long, respectively. The $190 \mathrm{~km}$ long Sob River takes source from the Polar Urals eastern slope, from a small glacial lake lying at $360 \mathrm{~m}$ above sea level.

The Khatanga River catchment lies above the Arctic Circle, in the permafrost zone. The $227 \mathrm{~km}$ long Khatanga River is formed by the confluence of the rivers Kheta $(604 \mathrm{~km})$ and Kotuya (1409 km), and discharges to Khatangsky Bay of the Laptev Sea [Surface...; 1964]. The study areas are shown in Fig. 1.

\section{Material and methods}

The samples of parasites from coregonid fish from Lower Ob Ural tributaries cover an extensive time period (1992, 1994-1996, 1998-2017). Altogether 3352 specimens of humpback whitefish (Coregonus lavaretus pidschian (Gmelin, 1788), peled Coregonus peled (Gmelin, 1789), least cisco Coregonus sardinella (Valenciennes, 1848), and tugun Coregonus tugun (Pallas, 1814) sampled during the spawning run (September-October) have been examined [Bykhovskaya-Pavlovskaya, 1985].

The parasite fauna of fish from the Khatanga River was surveyed in September 2011 and 2014. Altogether 117 fish (humpback whitefish, least cisco, peled, tugun) specimens have been dissected [Bykhovskaya-Pavlovskaya, 1985].

The species identification of parasites was carried out using keys to parasites of freshwa- 


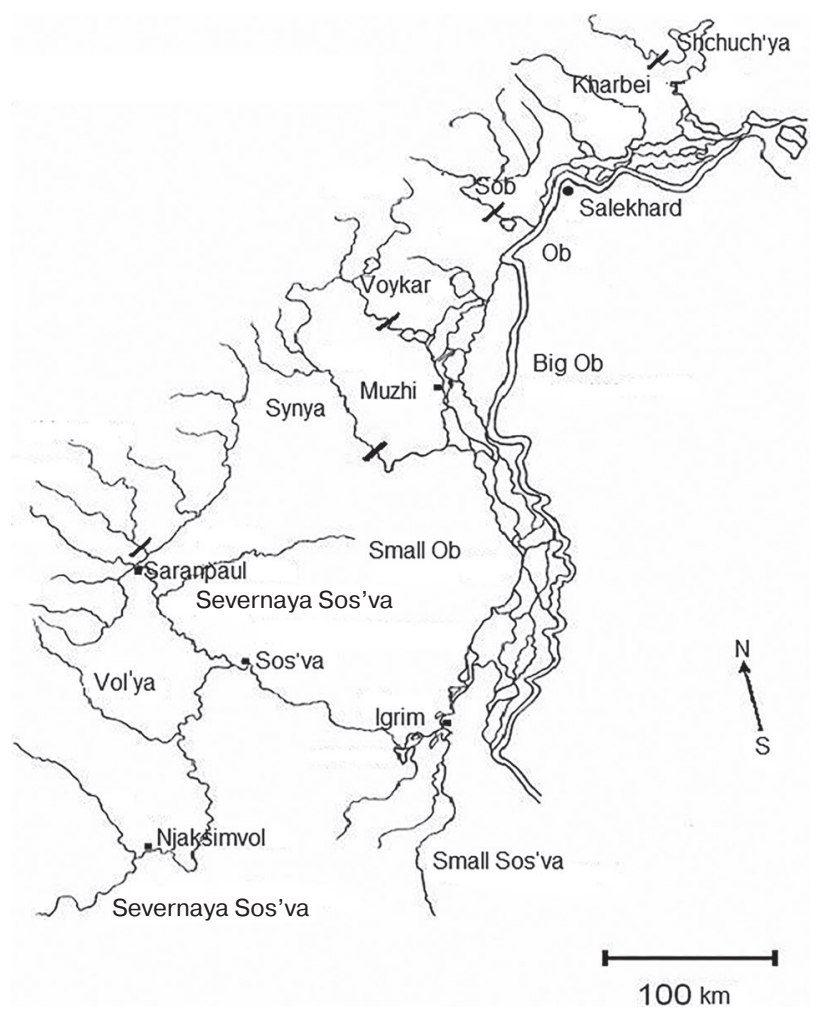

A

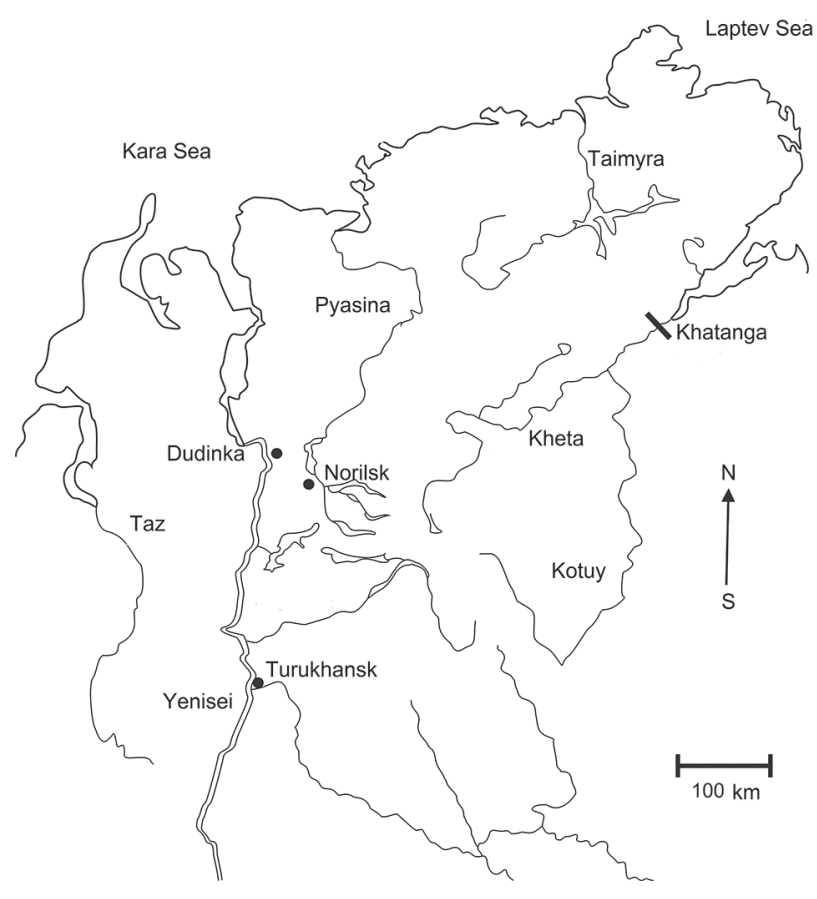

B

Fig. 1. A - Map of Lower Ob tributaries; B - Khatanga River system.

"-" marks the sampling sites.

ter fish [Keys..., 1984, 1985, 1987]. The similarity of the species compositions of parasites in coregonids was estimated by cluster analysis, principal components analysis [Korosov, Gorbach, 2007] using Past Statistics software [Hammer et al., 2001]. For the statistical analysis the table with data on the parasite fauna was converted into a matrix where the infection prevalence and intensity indices for individual parasitic species were represented by the number 1 where the species was present and by 0 where the species was absent.

Cluster analysis was performed using the Ward's method and Euclidian distance determination by calculating the bootstrap probability $(\mathrm{BP})$ based on ordinary bootstrap replication (500) that we used to plot dendrograms in PAST Ver. 2.17 [Hammer et al., 2001]. The plotted dendrograms are regarded reliable if the probability associated with branches of the bootstrap tree is above $70-80 \%$ [Shitikov, Rozenberg, 2013]. The research was carried out using the equipment of the Core Facility of the Karelian Research Centre of the Russian Academy of Sciences.

\section{Results}

The total record of parasites from coregonids from the Lower $\mathrm{Ob}$ and Khatanga catchments in- cludes 48 species: dermocystids - 1, flagellates 1 , myxosporidians -3 , infusorians -4 , monogeneans -3 , trematodes -10 , cestodes -7 , nematodes -6 , acanthocephalans -6 , crustaceans -5 , leeches -2 (Tabl.).

\section{Humpback whitefish Coregonus lavaretus pidschian (Gmelin, 1788)}

The parasite fauna of humpback whitefish in the catchments under study was made up of 32 species. Its richness in the Lower Ob catchment was not high (from 13 species in the Voykar River to 16 in the Severnaya Sos'va), and its members were parasites commonly recorded in lake-river systems.

The parasite fauna of humpback whitefish in the Khatanga was more diverse (23 species). It was noted for the presence of flagellates Spironucleus lato, cestodes Dibothriocephalus dendriticus (Nitzsch, 1824), Lühe 1899, Cyathocephalus truncatus (Pallas, 1781), Triaenophorus crassus Forel, 1868, Eubothrium salvelini Schrank, 1790, trematodes Phyllodistomum simile Nybelin, 1926, nematodes Camallanus lacustris (Zoega, 1776) and acanthocephalans Corinosoma strumosum (Rudolphi, 1802). It lacked dermocystids, infusorians (Trichodina sp. and Capriniana pisci- 


\begin{tabular}{|c|c|c|c|c|c|c|c|c|c|c|c|c|c|c|c|c|c|c|c|c|c|c|c|c|c|}
\hline \multirow{4}{*}{ 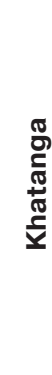 } & 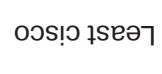 & ' & ' & ' & ' & ì & ' & ' & ' & & & & & & & & ' & . & ' & & ' & ' & 兑 & {$\left[\begin{array}{l}0 \\
\dot{\infty} \\
\infty\end{array}\right]$} & $\stackrel{m}{\stackrel{m}{g}}$ \\
\hline & undn $\perp$ & ' & ' & ' & ' & ' & 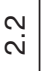 & ' & ' & $\stackrel{N}{N}$ & ' & ' & & ז & & $\begin{array}{r}\dot{f} \\
\dot{f}\end{array}$ & ' & ' & ' & $\begin{array}{l}\infty \\
\infty \\
\infty \\
\infty\end{array}$ & $\stackrel{N}{N}$ & ' & $\check{F}$ & $\begin{array}{l}\infty \\
\infty \\
\infty \\
q\end{array}$ & ' \\
\hline & 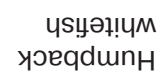 & ' & $\begin{array}{l}0 \\
0 \\
0\end{array}$ & 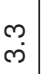 & . & $\stackrel{m}{m}$ & ' & ' & ' & ' & $\begin{array}{c}m \\
m\end{array}$ & & $\begin{array}{c}m \\
c\end{array}$ & 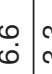 & 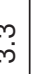 & $\stackrel{m}{m}$ & ' & ' & ' & 艿 & ' & ' & $\stackrel{m}{m}$ & $\begin{array}{l}\dot{\varphi} \\
\dot{\varphi}\end{array}$ & $\stackrel{m}{\stackrel{m}{c}}$ \\
\hline & $\begin{array}{r}\text { рәرəd } \\
\text { әu!ıısnวeา }\end{array}$ & . & ' & ' & ' & ' & ' & ' & ' & ' & . & ' & & ' & & ' & ' & ' & ' & $\begin{array}{l}\stackrel{\varphi}{\dot{\varphi}} \\
\stackrel{\varphi}{\leftarrow}\end{array}$ & $\begin{array}{c}m \\
\infty \\
\infty\end{array}$ & ' & 高 & $\begin{array}{l}m \\
\dot{m} \\
m\end{array}$ & 웅 \\
\hline \multirow{3}{*}{ 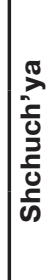 } & $\begin{array}{r}\text { pə|əd } \\
\text { əu!̣\}snoe } 7\end{array}$ & $\check{F}$ & . & ' & ' & $\check{\sigma}_{\dot{\sigma}}$ & ' & ' & ' & ' & ' & ' & & ' & & ' & $\stackrel{6}{\omega}$ & ' & ' & ֻุ & ' & ' & ' & $\frac{\sigma}{i}$ & $\begin{array}{l}\stackrel{0}{\circ} \\
\stackrel{\circ}{\square}\end{array}$ \\
\hline & oos!̣ ¡ łseəך & 응 & ' & ' & ' & ' & ' & ' & ' & ' & $\left|\begin{array}{ll}0 & \\
\tilde{N}\end{array}\right|$ & 文 & & 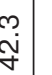 & & ' & ' & $\mid \begin{array}{c}n \\
N \\
N\end{array}$ & ' & 음 & ' & ' & ' & $\begin{array}{l}n \\
? \\
R\end{array}$ & $\begin{array}{l}0 \\
\dot{1} \\
\end{array}$ \\
\hline & unın $\perp$ & 1 & ' & ' & ' & ' & ' & ' & ' & ' & $\mid$ & & & ' & & ' & ' & ' & ' & 으 & $\begin{array}{l}0 \\
\dot{q} \\
\end{array}$ & ' & ' & $\begin{array}{l}0 \\
\dot{i}\end{array}$ & ' \\
\hline \multirow{5}{*}{ 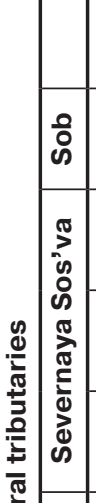 } & oวs!ฺ łseəך & $\left|\begin{array}{l}0 \\
\dot{q} \\
\dot{q}\end{array}\right|$ & ' & ' & $\cdot$ & $\overrightarrow{0}$ & ' & ' & ' & ' & $\begin{array}{l}m \\
m \\
m\end{array}$ & ' & ' & ' & ' & ' 1 & ' & . & ' & 으 & ' & ' & ' & $\begin{array}{l}m \\
\dot{m} \\
\dot{g}\end{array}$ & ' \\
\hline & undn $\perp$ & . & . & ' & ' & ' & ' & ' & ' & ' & $\left|\begin{array}{l}0 \\
i\end{array}\right|$ & ' & ' & ' & ' & ' & ' & . & ' & $\begin{array}{l}0 \\
\infty \\
\infty \\
\infty\end{array}$ & 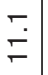 & ' & ' & ' & ' \\
\hline & unın $n_{\perp}$ & ' & ' & ' & ' & ' & ' & ' & ' & $\stackrel{\varphi}{\dot{\varphi}}$ & : & & & ' & & $\stackrel{0}{0}$ & ' & ' & ' & 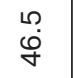 & 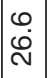 & ' & ' & $\begin{array}{l}\dot{0} \\
\dot{\varphi}\end{array}$ & $\stackrel{m}{\stackrel{m}{\longrightarrow}}$ \\
\hline & 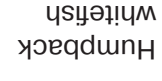 & $\mid \begin{array}{l}0 \\
\dot{d} \\
\stackrel{\leftrightarrow}{N}\end{array}$ & ' & $\stackrel{\circ}{\circ}$ & . & $\begin{array}{l}0 \\
\dot{0}\end{array}$ & ' & ' & ' & ' & $\begin{array}{l}\infty \\
\infty \\
\infty\end{array}$ & ' & & 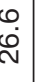 & & , & $\stackrel{\circ}{\circ}$ & . & $\begin{array}{l}0 \\
0 \\
0\end{array}$ & $\stackrel{8}{\circ}$ & $\mid \begin{array}{l}0 \\
\dot{\omega} \\
\stackrel{N}{*}\end{array}$ & ' & ' & $\begin{array}{l}\varphi \\
\dot{\varphi}\end{array}$ & $\stackrel{m}{\infty}$ \\
\hline & pә|әd & $\mid \begin{array}{l}0 \\
\dot{m} \\
\dot{m}\end{array}$ & $\stackrel{0}{\circ} \stackrel{0}{\circ}$ & ' & . & $\stackrel{m}{\sim}$ & ' & ' & ' & $\stackrel{\circ}{\underline{I}}$ & $\mid \begin{array}{l}0 \\
\dot{\rho} \\
i\end{array}$ & & & $\begin{array}{l}m \\
m \\
m\end{array}$ & & $\stackrel{\circ}{+}$ & $\stackrel{0}{6}$ & ' & ' & 음 & $\mid \begin{array}{l}0 \\
\infty \\
\infty\end{array}$ & ' & $\stackrel{0}{\dot{+}}$ & 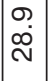 & $\stackrel{m}{m}$ \\
\hline \multirow{4}{*}{ 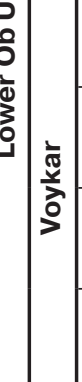 } & 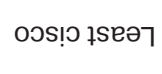 & ì & ' & ' & ' & $\begin{array}{l}0 \\
\dot{0} \\
\dot{0}\end{array}$ & ' & ' & ' & ' & $\begin{array}{l}\infty \\
\dot{\rho} \\
\underline{\rho}\end{array}$ & ' & ' & ' & ' & ' 1 & ' & ' & ' & 으 & ' & ' & ' & $\begin{array}{c}\infty \\
\infty \\
\infty \\
\infty\end{array}$ & ' \\
\hline & unın $\perp$ & . & ' & ' & ' & ' & ' & $\begin{array}{l}0 \\
\dot{0}\end{array}$ & ' & ' & $\mid \begin{array}{c}0 \\
\dot{o} \\
\dot{q} \\
\end{array}$ & & & ' & ' & i & $\begin{array}{l}0 \\
0 \\
0\end{array}$ & ' & ' & 음 & ' & ' & $\stackrel{0}{6}$ & : & $\stackrel{m}{m}$ \\
\hline & $\begin{array}{r}\text { 4syə!!yм } \\
\text { yoeqdun }\end{array}$ & $\mid \begin{array}{l}m \\
\infty \\
\infty\end{array}$ & ' & ' & ' & ' & , & $\begin{array}{l}m \\
m \\
m\end{array}$ & ' & $\check{E}$ & 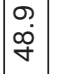 & & & ì. & & $\stackrel{0}{0}$ & $\begin{array}{l}0 \\
0\end{array}$ & ' & ' & 음 & ' & $\begin{array}{l}0 \\
\dot{0}\end{array}$ & ' & ' & $\stackrel{+}{\stackrel{\oplus}{\infty}}$ \\
\hline & pə|ə્d & $\mid \begin{array}{l}0 \\
\infty \\
\infty\end{array}$ & ' & $\begin{array}{l}0 \\
\dot{0}\end{array}$ & ' & 孞 $\stackrel{m}{\stackrel{m}{m}}$ & ' & ' & $\begin{array}{l}0 \\
\dot{0}\end{array}$ & ' & 步 & & & 吕 & & ( & $\stackrel{\varphi}{\dot{\varphi}}$ & ' & ' & 음 & $\mid \begin{array}{l}0 \\
\infty \\
\infty\end{array}$ & ' & $\stackrel{m}{\stackrel{m}{\infty}}$ & 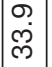 & זoj \\
\hline \multirow{4}{*}{ ڤે } & 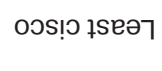 & $\left.\mid \begin{array}{l}0 \\
\infty \\
\infty \\
\end{array}\right]$ & ' & ' & ' & ' & ' & ' & ' & ' & $\left|\begin{array}{l}m \\
i \\
i\end{array}\right|$ & . & & $\dot{\sigma}$ & ' & ' & ' & $\mid$ & ' & 음 & . & ' & ' & $\mid \begin{array}{l}0 \\
\dot{\sigma}\end{array}$ & $\stackrel{\circ}{i}$ \\
\hline & undn $\perp$ & . & ' & ' & ' & ' & ' & ' & ' & ' & 孞 & & & $\dot{f}$ & & $\tilde{\sigma}$ & $\begin{array}{l}\infty \\
\infty \\
\infty\end{array}$ & ' & ' & $\overline{0}$ & $\left|\begin{array}{l}n \\
\infty \\
\infty \\
\infty \\
\infty\end{array}\right|$ & ' & ' & $\begin{array}{l}0 \\
\dot{+}\end{array}$ & ' \\
\hline & 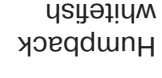 & $\mid$ & & $\begin{array}{l}0 \\
\dot{0}\end{array}$ & ' & $\stackrel{\circ}{-}$ & ' & ' & ' & ' & $\left|\begin{array}{c}N \\
N \\
N\end{array}\right|$ & & & 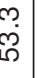 & & ' & $\stackrel{N}{N}$ & ' & ' & 으 & ' & ' & ' & $\begin{array}{l}m \\
\stackrel{m}{6}\end{array}$ & 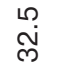 \\
\hline & pə|ə્d & $\left.\mid \begin{array}{l}\infty \\
\infty \\
\infty \\
\infty\end{array}\right]$ & ' & $\begin{array}{l}m \\
\stackrel{m}{m} \\
\stackrel{m}{~}\end{array}$ & $\stackrel{0}{\dot{0}}$ & 兑 & ' & ' & ' & ' & $\bar{m}$ & & & 它 & & & $\begin{array}{l}\widehat{N} \\
\infty\end{array}$ & $\cdot$ & $\begin{array}{c}\vec{m} \\
\stackrel{m}{\rho}\end{array}$ & 으 & $\begin{array}{l}m \\
\ddot{m} \\
-\end{array}$ & ' & $\begin{array}{l}\infty \\
\infty\end{array}$ & $\mid \begin{array}{l}\hat{\infty} \\
0 \\
0\end{array}$ & $\begin{array}{l}\hat{N} \\
\infty\end{array}$ \\
\hline & 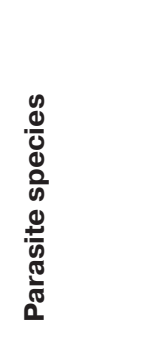 & 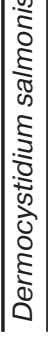 & 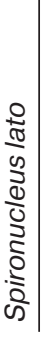 & 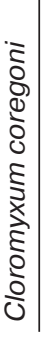 & 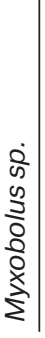 & 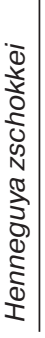 & 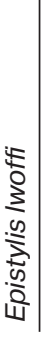 & 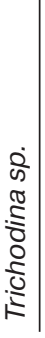 & 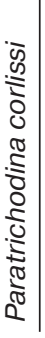 & 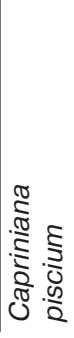 & 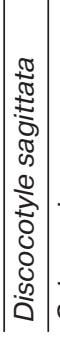 & 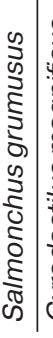 & 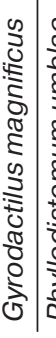 & 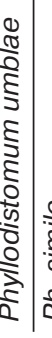 & 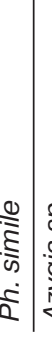 & 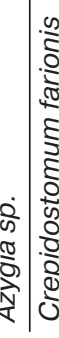 & 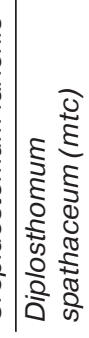 & 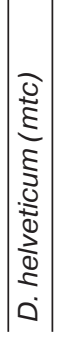 & $\begin{array}{l} \\
\dot{2} \\
\dot{0} \\
\dot{0}\end{array}$ & 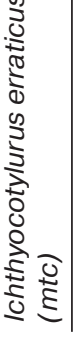 & 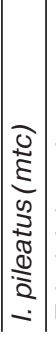 & 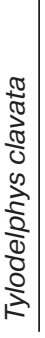 & 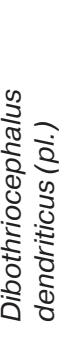 & 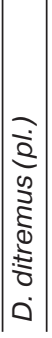 & 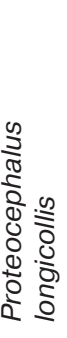 \\
\hline
\end{tabular}




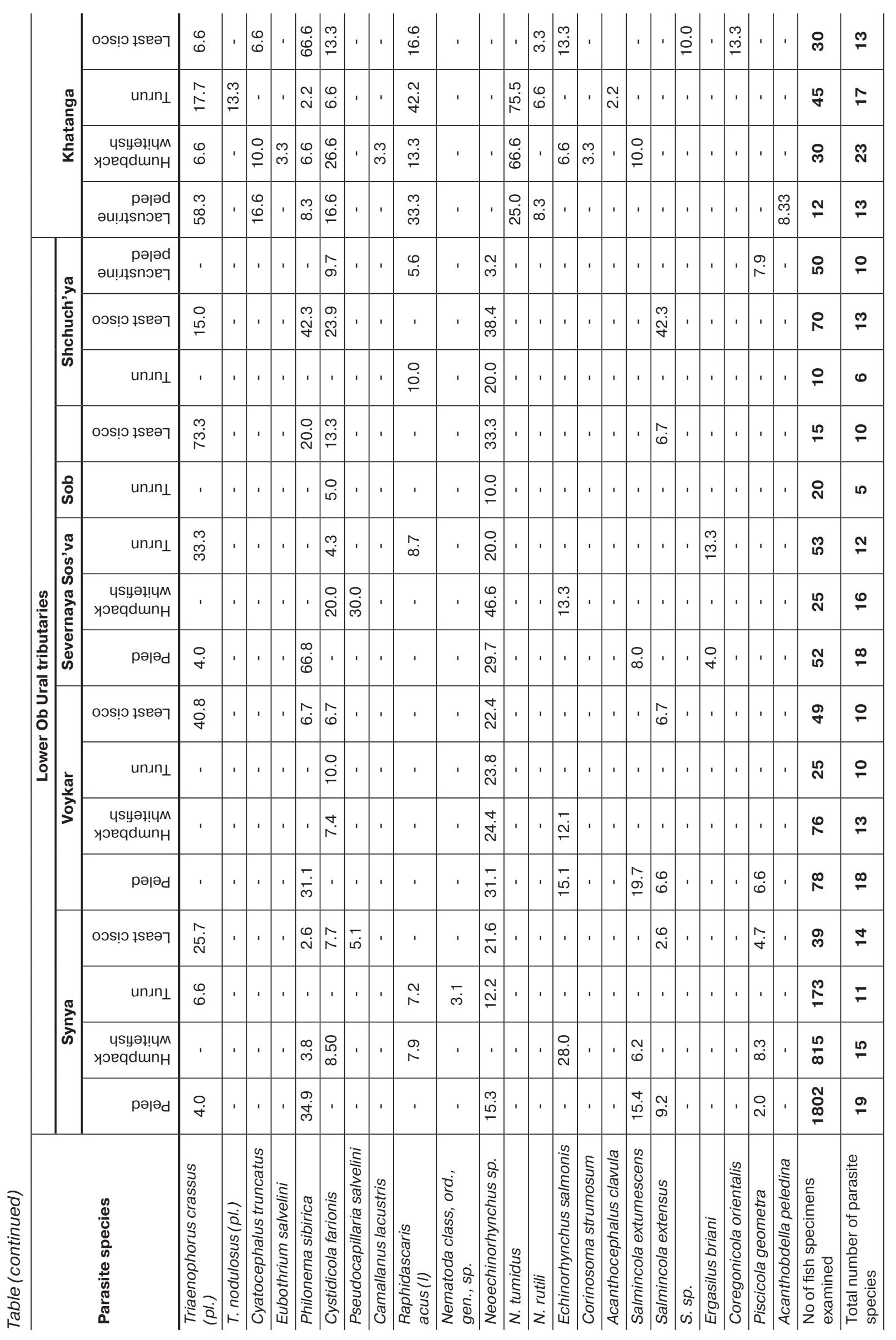




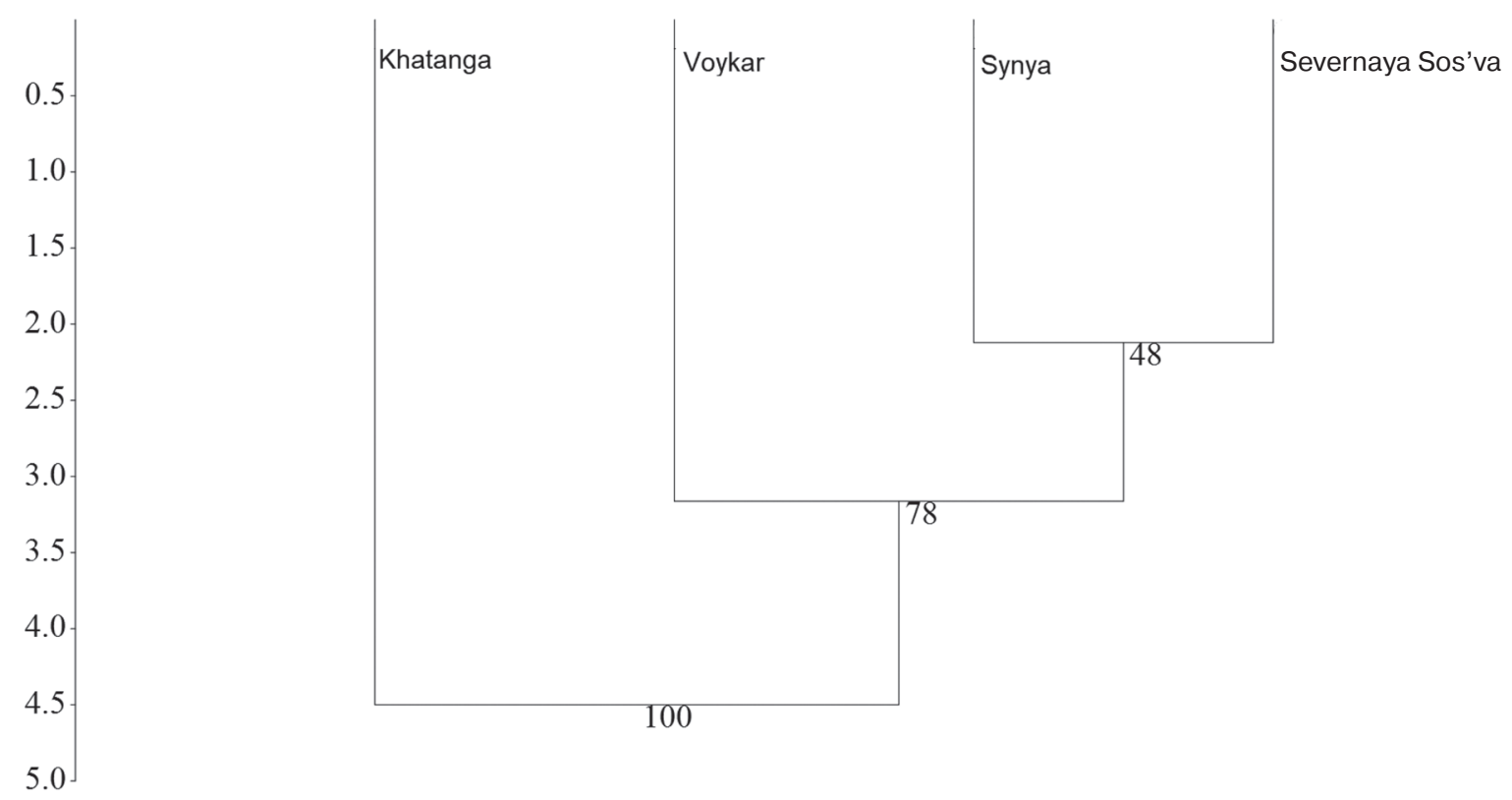

Fig. 2. Results of the cluster analysis of the parasite fauna differences in humpback whitefish from Lower Ob tributaries and the Khatanga River. Here and below cluster analysis was used (Euclidian distance, Ward's method); numbers stand for bootstrap probability (\%); the ordinate represents difference distances

um (Bütschli, 1889)), trematodes (Diplostomum spathaceum (Rudolphi, 1819), Diplostomum sp., Ichthyocotylurus pileatus (Rudolphi, 1802), nematodes Pseudocapillaria salvelini (Polyansky, 1952) and leeches Piscicola geometra (Linnaeus, 1761), occurring in humpback whitefish in Lower Ob tributaries.

The parasite fauna of humpback whitefish varied in composition among tributaries of the Lower Ob, the greatest distance shown for parasites from the Voykar (Fig. 2). The local parasite faunas of the fish from the Synya and Severnaya Sos'va were somewhat richer and more similar to one another. The species composition of parasites in the Khatanga stood apart, since some parasites were found only in whitefish from this river.

\section{Peled Coregonus peled (Gmelin, 1789)}

Peled samples from the surveyed rivers contained 31 parasite species. The number of species was the highest in semi-anadromous peled from the Synya (19); peled from each of the rivers Voykar and S. Sos'va hosted 18 species, the poorest parasite fauna was found in lacustrine peled from the Shchuch'ya - 10 species (see Table).

The least differences were observed for the parasite faunas of peled from the Synya and the Voykar (Fig. 3). Peled from these two rivers shared 16 species, there was a difference consisting of 5 species with minor difference in infection rates. The explanation is that the fish use the same $\mathrm{Ob}$ floodplain areas to forage before the spawn- ing run (mouths of the Synya and the Voykar are spaced less than $60 \mathrm{~km}$ apart). The parasite fauna of peled from the Sos'va River is similar in the species composition and prevalences to that of the Synya and Voykar. One of the main distinctions of the parasite faunas in these rivers is that peled from the S. Sos'va hosted flagellates, infusorians, trematode Crepidostomum farionis (Mueller, 1780), crustacean Ergasilus briani Markewitsch, 1932, but lacked leeches.

The parasite fauna of lacustrine peled from the Khatanga was poor (13 species). While foraging in lakes, peled get infected by the trematode I. pileatus and the leech-like annelid Acanthobdella peledina Grube, 1851, which are absent in the other coregonids. However, the peled did not contain the monogenean Discocotyle sagittata (Leuckart, 1842), which is very typical for lake systems. Since the Khatanga is geographically the northernmost river among those in the study, it is possible that the monogeneans are at the limit of their distribution range, and therefore scant. Infestation by other parasite species could happen either in the lake or in the river. The high prevalences of the cestodes Proteocephalus longicollis (Zeder, 1800), (50.0\%) and $T$. crassus $(58.3 \%)$, however, suggest that peled mostly get infected while foraging in lake systems, where the conditions for zooplankton are the most favorable. Note that differences between the parasite faunas of peled lacustrine ecotypes (Rivers Shchuch'ya and Khatanga) are relatively low, despite the significant geographical distance between these rivers.

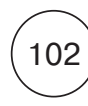




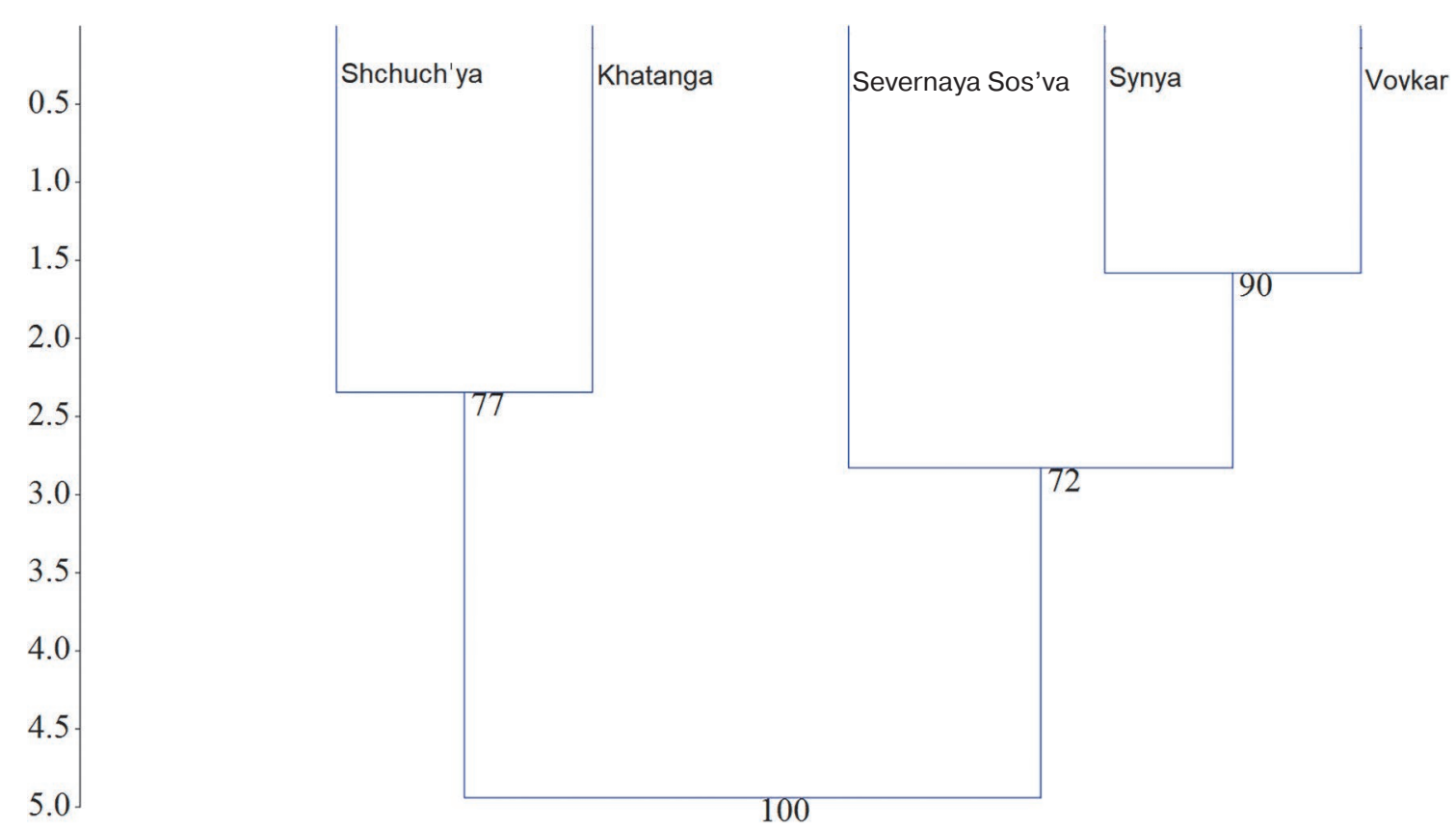

Fig. 3. Results of the cluster analysis of differences for the parasite fauna of peled from Lower Ob tributaries and the Khatanga River

The cluster analysis of the parasite fauna of the peled has reliably grouped lacustrine ecotypes from the Shchuch'ya and the Khatanga into one cluster, and anadromous peled from the Synya, Voykar and S. Sos'va into another. Among Lower Ob tributaries, the parasite fauna of fish from the upstream tributary - S. Sos'va, diverged the most, and the smallest differences were revealed between the rivers Synya and Voykar (Fig. 3).

\section{Least cisco Coregonus sardinella (Valenciennes, 1848).}

Least cisco samples contained 23 species of parasites belonging to nine taxonomic groups. The number of parasite species in Lower Ob tributaries ranged from 10 to 14, in the Khatanga it was 13 species. The catchments of the two rivers shared sixspecies, and four of them were widespread parasites of coregonids whose life cycle involves zooplankton (Dibothriocephalus ditremus (Creplin, 1825) Lühe, 1899), Proteocephalus Iongicollis (Zeder, 1800), T. crassus Forel, 1868, Philonema sibirica (Bauer, 1946)).

Least cisco from the Voykar and the Sob had similar parasite faunas (Fig. 4). The rivers Synya and Shchuch'ya, although different in a number of hydrobiological parameters [Bogdanov et al., $2002,2005]$, showed a high similarity of the faunas, owing to the presence of 12 parasite species common for both rivers. Nematodes $P$. salveli$n i$ and leeches $P$. geometra, which are apparent- ly rather rare in the Lower Ob catchment, were found only in cisco from the Synya. Metacercariae of Ichtyocotylurus erraticus Szidat, 1925 were the main dominant species in terms of prevalence and intensity in all Lower Ob tributaries. Overall, the parasite fauna of cisco from these rivers was noted for the presence of freshwater species Dermocistidium salmonis (Davis, 1947), D. sagittata, metacercariae of trematodes of the genus Diplostomum, as well as acanthocephalans $\mathrm{NeO}$ echinorhynchus sp., suggesting that the fish spend most of their lives in the southern freshwater part of the Gulf of $\mathrm{Ob}$, without prolonged foraging or wintering migrations to brackish waters of the gulf.

The parasite fauna of least cisco in the Khatanga River consisted of species with direct (crustaceans Salmincola sp. and Coregonicola orientalis Markewitsch et Bauer, 1950) and complex (five species of each 'planktic' and 'benthic' parasites) lifecycle, as well as one species (Henneguya zschokkei Gurley, 1894) infesting the fish percutaneously. Seven of the 13 species in the fauna have been found only in least cisco from the Khatanga, wherefore the difference distance for the parasite fauna of the Khatanga fish is reliable and the greatest compared to fish from Lower Ob tributaries (Fig. 4).

\section{Tugun Coregonus tugun (Pallas, 1814)}

The tugun is a Siberian endemic, and the most thermophilic species among Siberian coregonids. Tugun yielded 24 parasite species, their number being the highest in the rivers Khatanga (17) 


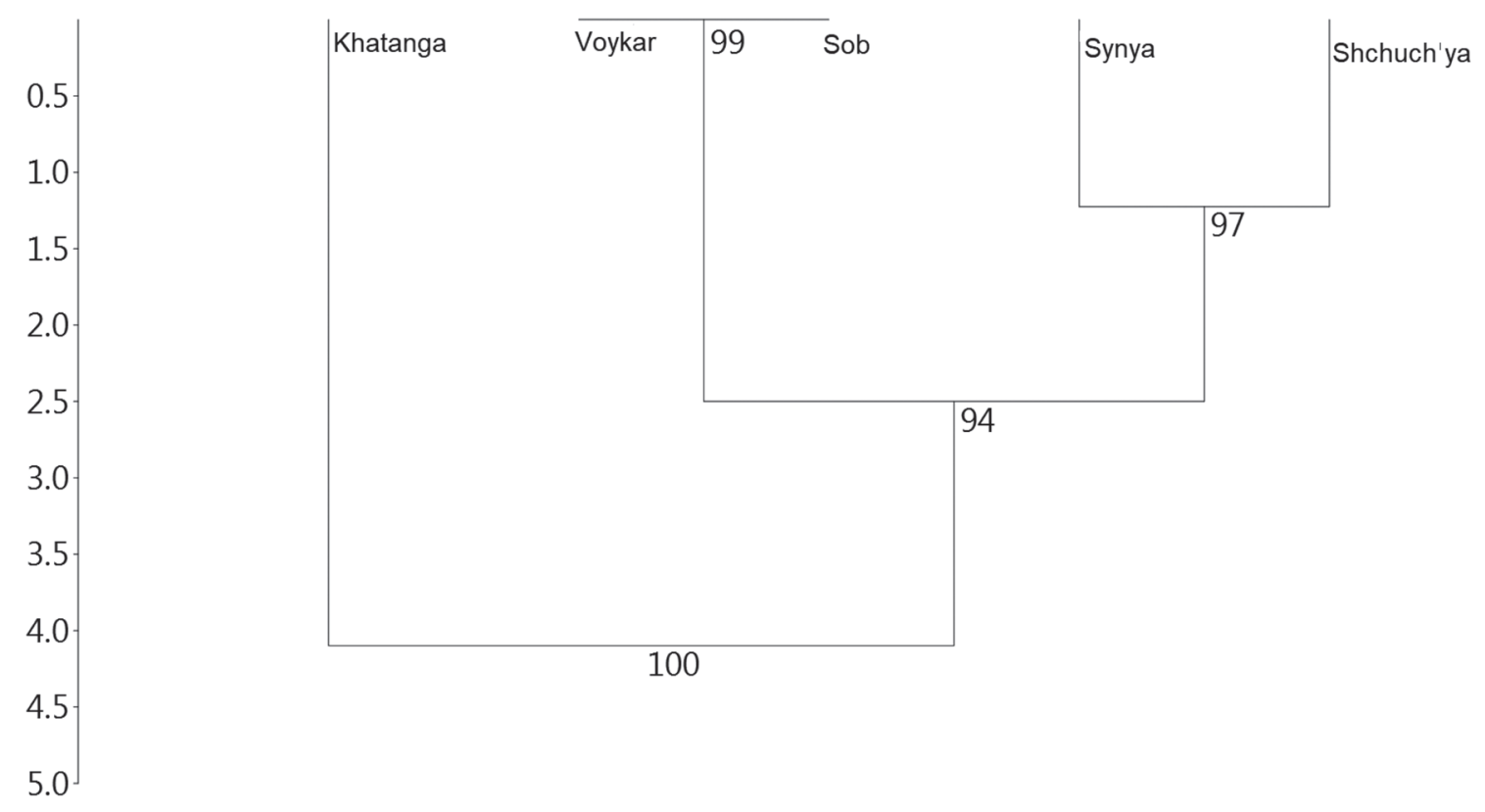

Fig. 4. Results of the cluster analysis of differences for the parasite fauna of least cisco from Lower Ob tributaries and the Khatanga River

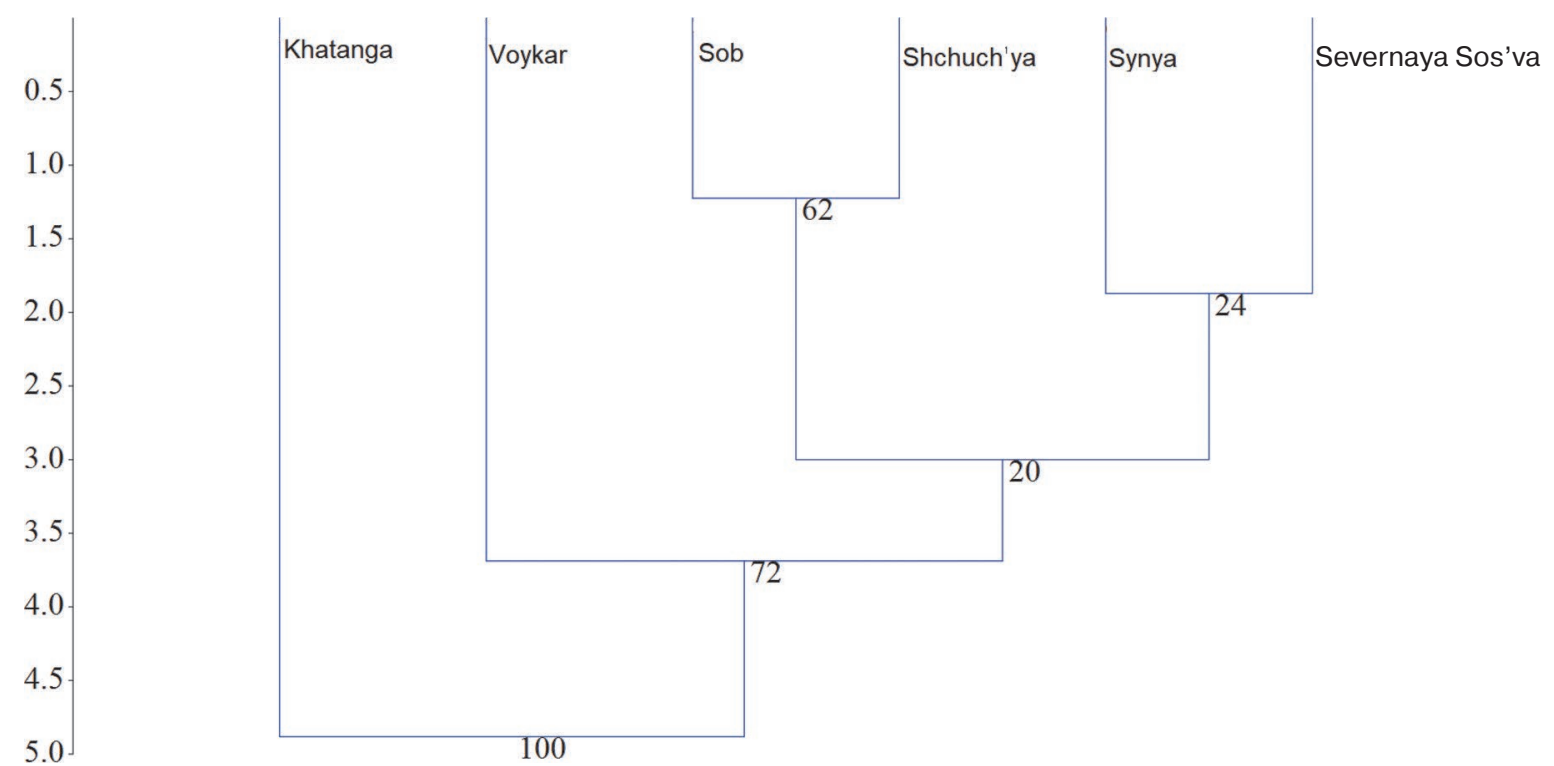

Fig. 5. Results of the cluster analysis of differences for the parasite fauna of tugun from Lower Ob tributaries and the Khatanga River

and S. Sos'va (12), and the lowest in the Sob (5) and Shchuch'ya (6). The Lower Ob and Khatanga catchments share 10 and differ in 13 parasite species. Thus, the monogenean $D$. sagittata was found in coregonids from all the Ob tributaries but was absent in tugun from the Khatanga. Vice versa, the nematode $P h$. sibirica - a widespread parasite of coregonids, was missing from tugun from rivers of the Lower $\mathrm{Ob}$ catchment. The parasite fauna of tugun differed significantly both among Lower Ob tributaries and as compared with the Khatanga River, whose difference distance was the greatest (Fig. 5).
The least different were the parasite faunas of tugun from the rivers Shchuch'ya and Sob, while the parasite fauna of fish from the Voykar River stood apart, since its tugun foraged in Lake Varchato along the river's main channel rather than in the river's floodplain (Fig. 5). In the rivers Synya and Sos'va (southerner Ural tributaries) tugun were found to host similar numbers of species (11 and 12, respectively) and their compositions were also similar ( 8 species shared). The distinctive features of the parasite fauna of tugun were the absence of $D$. salmonis, which occurred in semi-anadromous coregonids in all Lower $\mathrm{Ob}$ 


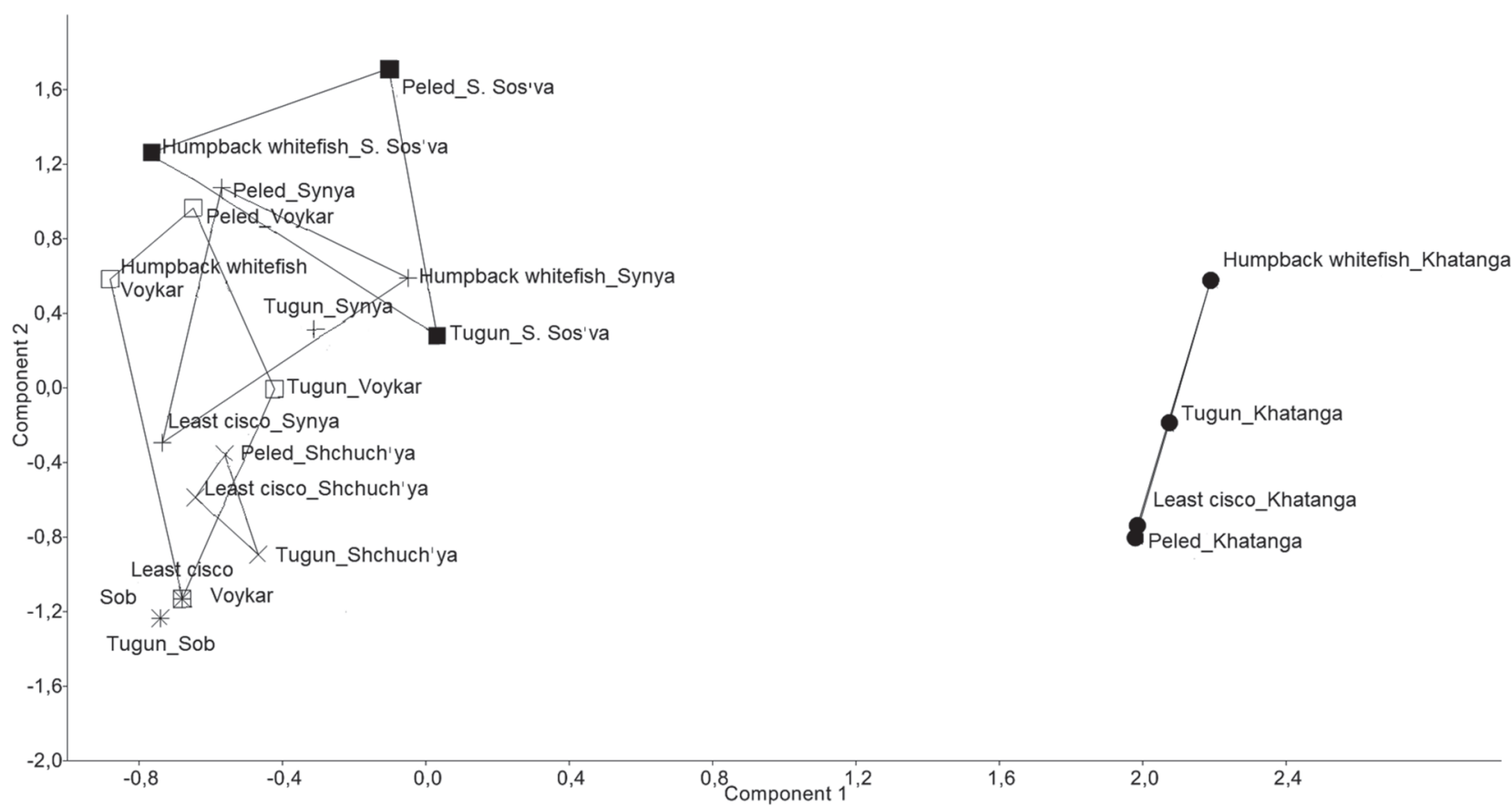

Fig. 6. Estimation of the differences between the parasite faunas of the coregonids spawning in Lower Ob tributaries and the Khatanga River using principal components analysis; percentage of explained variance for component 1 (40.5\%), for component $2(28.4 \%)$

tributaries, and the high prevalence of $T$. crassus plerocercoids (33.3\%) in the Sos'va River.

\section{Discussion}

The species richness of parasites hosted by coregonids in Lower Ob tributaries and in the Khatanga River was represented by the same number of species - 33, with the majority of them being widespread in Siberian waters. The parasites shared by fish from Lower Ob Ural tributaries and the Khatanga River were myxosporidians $H$. zschokkei, monogeneans $D$. sagittata, cestodes $D$. ditremus ( $p l), T$. crassus ( $p l)$, trematodes l. erraticus ( $m t c$ ) and $l$. pileatus ( $m t c)$, nematodes $\mathrm{Ph}$. sibirica. The most common were metacercariae of $I$. erraticus, which infected all the studied hosts. A majority of the rivers also had $D$. salmonis, cestodes $P$. longicollis and trematodes Phyllodistomum umblae Fabricius, 1780. Rarely occurring parasites were Epistylis Iwoffi Faure'- Fremiet, Trichodina sp., Paratrichodina corlissi Lom et Haldar, 1977. An accidental species in the parasite fauna of the fish in the Khatanga River was G. magnificus - a specialist parasite of minnow.

Although the similarity of the parasite faunas of coregonids in the Lower $\mathrm{Ob}$ and the Khatanga catchments was quite high (altogether 19 species in common), there were some substantial differences (Fig. 6). Fish from all rivers of the Lower Ob catchment contained $D$. salmonis, while fish from the Khatanga lacked this species. Parasitic infusorians were more widely represented in whitefish from the Lower $\mathrm{Ob}$ catchment -3 species that were absent in fish from the Khatanga River out of the 4 in total. On the contrary, coregonids from the Khatanga were found to host 7 cestode species missing from the Lower $\mathrm{Ob}$ catchment. The trematode fauna in the Khatanga River was mostly made up of the species for whom fish is the definitive host (4 out of 6 species), whereas in the Lower Ob catchment dominance (6 out of 8 species) belonged to the parasites whose life cycle terminates in birds. The Lower Ob catchment offers a system of intermittent waterbodies (sor), which are rather shallow and rich in fish, favoring the abundance of piscivorous birds.

Among the five species of parasitic crustaceans, Salmincola extumescens (Gadd, 1901) was present in fish from both catchments, E. briani only in fish from the S. Sos'va River, and C. orientalis in least cisco from the Khatanga. Coregonicola, which is a common parasite in coregonids in brackish waters of the gulfs of the Kara Sea and Laptev Sea, is introduced into rivers during the spawning run. In the Lower Ob catchment $C$. orientalis was found in the Novy Port and Messoyakha populations of the least cisco foraging before the spawning run in the brackish waters of the northern Gulf of Ob [Osipov, 1984]. Another coregonicola species, Coregonicola producta Markewitsch, 1936, has previously been reported from the lower course of the Ob River [Petrushevsky et al., 1948], 
but this species did not occur in semi-anadromous coregonids in our surveys, suggesting that the fish foraged and overwintered only in the freshwater southern part of the Gulf of Ob.

Marine parasites included $C$. strumosum, retrieved from whitefish from the Khatanga River, whose intermediate host is the amphipod Monoporeia affinis (syn. Pontoporeia affinis) (Lindström, 1855). Parasitic leeches were represented by two species: the widespread $P$. geometra was found in fish from the rivers Synya, Voykar and Shchuch'ya but was missing in fish from the Khatanga, while peled from the Khatanga hosted the leech-like annelid $A$. peledina, which was not found in fish from the Lower Ob catchment.

Generally speaking, significant differences are seen when comparing the parasite faunas of coregonids in the two river catchments. The parasite faunas of Lower Ob tributaries are similar and overlapping for most of the rivers (Fig. 6), apart from the S. Sos'va River, which deviates somewhat. The parasite fauna of the coregonids spawning in the S. Sos'va River is not only rich but also the most diverse in terms of the species composition. The greatest similarity has been demonstrated for the parasite faunas of fish from the rivers Shchuch'ya and Sob.

The parasite fauna of fish from the Khatanga River has the greatest difference from that of the Ural tributaries. The results we obtained are probably explained by the geographical location of the rivers, their hydrological and thermal parameters, foraging resources and the general life patterns of the fish in these catchments.

This study was carried out within the state assignment of the Institute of Plant and Animal Ecology, Ural Branch, Russian Academy of Sciences, and partially supported by the integrated program of the Presidium of the Ural Branch of the Russian Academy of Sciences (№ AAAA-A19-119031890085-3), and under the state order of the Karelian Research Centre of the Russian Academy of Sciences (0218-2019-0075).

\section{References}

BauerO.N. On the study of fishes parasites of the Khatanga River. Proceed. Sci. Research Inst. Polar. Agriculture and Fishery. 1941. Vol. 16. P. 121-125.
Bogdanov V. D., Bogdanov E. N., Goskova O. A., Stepanov L. N., larushina M. I. The ecological state of the tributaries of the lower Ob (the Synya River, Voikar, Sob). Ekaterinburg: Ural Branch of RAS, 2002. 135 p.

Bogdanov V. D., Bogdanova E. N., Goskova O. A., Melnichenko I. P., Stepanov L. N., Iarushina M. I. Ecological state of the tributaries of the lower Ob (Kharbei River, Longgotyegan, Shchuchya). Ekaterinburg: Ural Univ., 2005. 235 p.

Bykhovskaya-Pavlovskaya I. E. Parasites of fishes. Study guide. Leningrad: Nauka, 1985. 122 p.

Chugunova Yu. K., Budin Yu. V. Parasitofauna of whitefish in the Khatanga River. The current state. Fisheries reservoirs of Russia: fund. and appl. research: Mat. Il All-Russ. Sci. conf. (St. Petersburg, April 2-4, 2018). St. Petersburg, 2018. P. 682-687.

Gavrilov A. L., Bogdanov V. D., leshko E. P. Peculiarities of infestation with parasites of the Siberian whitefish Coregonus sardinella (Valenciennes, 1848) in the Ural tributaries of the lower Ob. Ecol. 2013. No. 1. P. 46-52.

Hammer Ø., Harper D. A. T., Ryan P. D. PAST: Paleontological statistics software. Package for education and data analysis. Palaeontologia Electronica. 2001. Vol. 4, no. 1.9 p.

Key to parasites of freshwater fish of the USSR. Leningrad: Nauka, 1984. Vol. 1. 428 p.

Key to parasites of freshwater fish of the USSR. Leningrad: Nauka, 1985. Vol. 2. 425 p.

Key to parasites of freshwater fish of the USSR. Leningrad: Nauka, 1987. Vol. 3. 383 p.

Korosov A. V., Gorbach V. V. Computer processing of biological data: A manual. Petrozavodsk: PetrSU, 2007. $76 \mathrm{p}$.

Lukyanchikov F. V., Cherepanov V. V. Parasites of fishes of the Khatanga River. News of the East Siberian Geographical Society of the USSR. 1962. Vol. 60. P. 67-80.

Osipov A. S. Parasite fauna of Siberian whitefish, from various areas of its habitat in the north of the Tyumen Region. Proceed. Research Inst. on Lake and River Fisheries (GosNIORH). 1984. Vol. 226. P. 32-35.

PetrushevskyG. K., Mosevich M. V., Shchupakov I. G. Fauna of the parasites of the $\mathrm{Ob}$ and Irtysh fishes. Izv. VNIORH. 1948. Vol. 27. P. 67-97.

Reshetnikov Yu.S. Ecology and systematics of whitefish. Moscow: Nauka, 1980. 302 p.

Resources of a surface water resources of the USSR. Hydrological knowledge. Leningrad: Gidrometeoizdat, 1964. Vol. 17, iss. 6. 222 p.

Shitikov V., Rozenberg G. Randomization and bootstrap: a statistical analysis in biology and ecology using R. Toliatti: Kassandra, 2013. 314 p.

Titova S. D. Parasites of fishes of Western Siberia. Tomsk: Tomsk Univ., 1965. 172 p.

Received December 26, 2018 


\section{СВЕДЕНИЯ ОБ АВТОРАХ:}

\section{Гаврилов Александр Леонидович}

научный сотрудник

Институт экологии растений и животных УрО РАН

ул. 8 Марта, 202, Екатеринбург, Россия, 620144

эл. почта: gavrilov@ipae.uran.ru

тел.: (343) 2103858 (доб. 113)

\section{Чугунова Юлия Константиновна}

научный сотрудник, к. б. н.

Всероссийский научно-исследовательский институт

рыбного хозяйства и океанографии, Красноярский филиал

ул. Парижской Коммуны, 33, Красноярск, Россия, 660097

эл. почта: jhermann@mail.ru

\section{Иешко Евгений Павлович}

главный научный сотрудник лаб. паразитологии животных и растений, д. б. н., проф.

Институт биологии КарНЦ РАН,

Федеральный исследовательский центр

«Карельский научный центр РАН»

ул. Пушкинская, 11, Петрозаводск, Республика Карелия,

Россия, 185910

эл. почта: ieshko@krc.karelia.ru

\section{Госькова Ольга Александровна}

научный сотрудник, к. б. н.

Институт экологии растений и животных УрО РАН

ул. 8 Марта, 202, Екатеринбург, Россия, 620144

эл. почта: goskova@ipae.uran.ru

тел.: (343) 2103858 (доб. 113)

\section{Богданов Владимир Дмитриевич}

главный научный сотрудник, заведующий лабораторией, чл.-корр. РАН, д. б. н., проф.

Институт экологии растений и животных УрО РАН

ул. 8 Марта, 202, Екатеринбург, Россия, 620144

эл. почта: bogdanov@ipae.uran.ru

тел.: (343) 2102959

\section{CONTRIBUTORS:}

Gavrilov, Alexander

Institute of Plant and Animal Ecology, Ural Branch,

Russian Academy of Sciences

$2028^{\text {th }}$ Marta St., 620144 Ekaterinburg, Russia

e-mail: gavrilov@ipae.uran.ru

tel.: (343) 2103858 (dob. 113)

Chugunova, Yulia

Russian Federal Research Institute of Fisheries and Oceanography, Krasnoyarsk Branch

Parizhskoy Kommuny St., 660097 Krasnoyarsk, Russia e-mail: jhermann@mail.ru

\section{leshko, Evgeny}

Institute of Biology, Karelian Research Centre,

Russian Academy of Sciences

11 Pushkinskaya St., 185910 Petrozavodsk, Karelia, Russia e-mail: ieshko@krc.karelia.ru

\section{Gos'kova, Olga}

Institute of Plant and Animal Ecology, Ural Branch, Russian Academy of Sciences

$2028^{\text {th }}$ Marta St., 620144 Ekaterinburg, Russia

e-mail: goskova@ipae.uran.ru

tel.: (343) 2103858 (dob. 113)

Bogdanov, Vladimir

Institute of Plant and Animal Ecology, Ural Branch, Russian Academy of Sciences

$2028^{\text {th }}$ Marta St., 620144 Ekaterinburg, Russia

e-mail: bogdanov@ipae.uran.ru

tel.: (343) 2102959 